\title{
Parks, People, and Population
}

The scenario is virtually perfect, as befits the name of Gran Paradiso. It is the oldest of Italy's fine national parks, and we are in the heart of its 620 square kilometres-at an altitude of nearly 2,800 metres, sitting on a carpet of brilliant middle-alpine flowers. About a dozen Ibex graze around, using their long curved horns to scratch their haunches by bending their necks almost double, and there are Chamoix and plentiful shrill-calling Marmots in the vicinity. Overhead a Raven croaks, while among the rocks a few metres ahead of us two superb Ibex turn lazily in the heat of the midday sun, as we look around for signs of overgrazing but happily find none. The stream rushes on, charged with ice-cold melt-water from the glaciers and patches of névé on the higher slopes. The sedgy-grassy middle-alpine plains are well watered, even in early August, and comprise over wide areas a fine patchwork quilt of mostly dwarf but brilliant flowers. There is a wealth and often range of species of Gentiana, Myosotis, Eritrichium, Viola, and Campanula, among the blues, Ranunculus, Draba, and various composites, among the yellows, with white and pink caryophylls and legumes, and several other colours well represented - also by numerous butterflies and day-flying moths. Almost every square metre provides a veritable rock-garden of varying fascination.

Released, as it were, from years of toilsome setting up of universities in hot countries and subsequently the bondage imposed by acute recognition of the world's deteriorating environmental situation, we suddenly come upon a potentially rather significant realization. Here we are, surrounded by this splendid range of our main floristic friends of still earlier, arctic explorational days. Sometimes they are the selfsame species, thus having a truly arctic-alpine range, but very often they are allied congeneric species having, doubtless, similar ecological needs and habitat impress to those of their relatives. These "ecological counterparts' appear to have much the same environmental requirements and, reciprocally, effects on their habitats, as their arctic congeners; over and over again one wondered why something was apparently missing -only to find it or a counterpart somewhere nearby in another community belonging to the same general ecosystem. Presumably the Pleistocene ice-age, with its evident aftermath, has been a contributory factor in this, but no more. Consequently we formulated mentally, for subsequent enunciation if it should stand the test of due further consideration, what we think of provisionally as the 'Principle of Ecosystem Completion'. At least is should fare better than our somewhat comparable 'Principle of Reaction Similarity', published many years ago in Science but long since forgotten even by its author!
Exhilerated by the free alpine air and towering mountains, we marvelled at the beauties of Nature and formulated this 'Principle of Ecosystem Completion' as follows: Natural ecosystems normally are balanced entities having more or less numerous components, both living and inert, drastic change in any one of which can radically affect the whole, and removal of any one of which can be fatal to the ecosystem per se. In the matter of biota, filling of any ecological niche by ecological counterparts - as between different arctic or alpine species of the same genus-may be effective, but lack of any major component of an ecosystem or lower econ may be indicative of instability, and its removal is to be deprecated. For instance, what will happen to the remaining plants and dependent Caribou and other animal denizens of the North Slope of Alaska if the planned oil development widely decimates the tundra lichens in the manner that some preliminary studies have indicated? Alternatively, imposition in the form of introduced plants and animals can have devastating outcomes, and introductions of exotics should not be indulged in without prior ecological study and full consideration of their possible effects. Yet the vegetational disruption so widely effected by Man all too commonly leads to the spread of exoticswith results that are often disruptive and sometimes disastrous.

To ranking ecologists all this may seem like 'old hat' and probably is: but we record these thoughts as hopefully clarifying the situation in some other minds, and at least affording a working hypothesis. Our thoughts on ecosystem completion certainly became consolidated in our own minds as we climbed up into the high-alpine zone to a pass at about 3,300 metres, where Purple Saxifrage (Saxifraga oppositifolia) and a counterpart of the tussocked arctic Moss Campion (Silene acaulis) were abundant and often preponderant as components of the biomass, and then started our long descent.

Back again on a well-trodden path littered with rusting (and hence not so bad, as ultimately disappearing) metal containers, empty bottles, and bits of plastic (probably the worst of all, being bright-coloured and seemingly permanent; we can only hope for more use of biodegradable plastics than at present seems commercially feasible), we were again among groups of noisy if often colourful people, despoiling the superb countryside with more of their detestable litterenjoying Nature we hoped, and deserving to from the effort of getting there, but certainly not helping to preserve her pristine state. And below at the Refugio the rubbish was being dumped into the fine rushing torrent-again, quite unnecessarily. For a single pit could take the year's garbage, or the mule which daily 
bore up supplies could carry back the residual fraction to the populous valley below.

We had enjoyed again the unique exhileration of the heights, the stimulation of wild Nature, and so had our younger, schoolboy son who had begged us to come thither. But what of future generations? Without such possibilities which have surely helped to make him the best of what he is, Man would lose much and never be the same again. He used to fear wild animals and wild places, but now he has Nature alarmingly at bay. Has he not become far too heavily the superdominant of the world? I fear so, and plan to spend my remaining years to do what little an individual can to counter this devastating tendency towards 'development' without conservation, whereas the two can and should go together. The biosphere is quite dangerously fragile, and we must do everything in our power to preserve it as best we can.

Outstandingly, these often superb National Parks that now dot the world in most enlightened countries, must be preserved and increased to give our descendants some chance of enjoying wild Nature. Thus alone can future generations experience what life on Earth was like before all else was put at bay by the devastating onslaught of rising human population making ever-increasing demands on the limited resources of Planet Earth. This surely poses the greatest set of problems which Man and Nature have ever faced. Yet there are still many countries and huge areas of land-let alone the deteriorating oceans and seas covering more than $70 \%$ of the surface of the globe-that have no national parks or equivalent reserves, and these must be tackled and their inhabitants helped to see the light. They must be persuaded to set up National Parks and Nature Reserves - for human enjoyment and scientific enlightenment or at least as a matter of national prestige-and such parks and reserves must be held inviolate against all the inevitable pressures and regardless of the cost.

But how do we render major areas inviolable in the face of ever-increasing human population pressures and their understandable demands despite the finite nature of the world? It is a very difficult and sometimes intractable problem, requiring firm governmental action based on enlightened policy. The fundamental need towards attaining this goal is, surely, sound education for the future; we must catch the very young. But we cannot wait until they grow up to take over the leadership when it is authoritatively predicted the world will already have double its present population of around four thousand million humans.

As indicated by Professor Paul R. Ehrlich, writing in our initial issue, many of the most enlightened demographers and ecologists think this will not happen, that 'there is no means of avoiding a [catastrophic] rise in the world's death-rate', and already there are signs that they may be right. The spectre of famine hangs now over more people in the world probably than ever before, with much of India and northern Africa most notably 'in the lead' but by no means alone in this appalling sense. The widespread development of nuclear energy also poses grave problems and introduces 'unacceptable risks' according to many who have studied the situation dispassionately. And then there are some who believe that, with food and other shortages rampant, people will kill one another in sufficient numbers to stem the present seemingly inexorable rise in human population. Thus there appears to be at least a considerable chance that the currently predicted doubling and then doubling again of the world's human population will never take place. Think of the effect of a devastating influenza or other viral pandemic on a world already weakened and disrupted by famine, nuclear holocaust, and general strife; it could quite foreseeably end life as we know it, and hideously decimate Nature.

Yet Man widely continues in his foolhardy way, risking everything in his selfish greed. Thus there are national and political interests which continue to urge him to develop and multiply infernal machines that in some enlightened scientific minds could risk the termination of all life on Earth, there are commercial interests encouraging inexcusably profligate waste, and there are even religious and other insistencies that Man should go on breeding as prolifically as he can. All this must stop, and surely will stop - even if the lesson is the hardest the world has ever learnt, costing many hundreds of millions of human lives. At present the production of food is rising-where it is increasing at all-insufficiently to keep abreast of overall human population rises, and this is at the expense of depletion of irreplaceable fossil fuels, short-lived cultivation through turning of 'marginal' lands into eroded wastes, over-fishing and pollution of the oceans and seas, degradation of lakes and rivers into virtual sewers, clear-cutting of forests which will not return in centuries or will never return, and so on-we all know the dismal prospects. And with major famines, what would happen to the Elephants of Tsavo, the Redwoods of California, the Ibex and Chamoix of Gran Paradiso?

Wise minds-who may well turn out to be prophets-paint a very gloomy, in some cases hopeless, picture of the future. We ourselves feel that Man, with his unique intelligence, is just too cunning to exterminate himself, though it seems inevitable that his life will change, and with it the life of many other creatures-some with extinction. Yet hope lies in Man's intelligence and resilience-coupled with the extraordinary resilience of many components of Nature. And so we soldier on, striving for something better than the worst, though unless we mend our profligate ways both soon and widely, it may not turn out to be much better than this foreseeable worst.

N. P. 